\title{
Macroinvertebrates of the Tributaries of Upper Baleh River, Sarawak
}

\author{
ANITA MULI* ${ }^{* 1}$, NYANTI LEE ${ }^{2}$, TECK-YEE LING², SIONG-FONG SIM² \& JONGKAR \\ GRINANG ${ }^{1,2}$ \\ ${ }^{1}$ Institute of Biodiversity and Environmental Conservation, Universiti Malaysia Sarawak, 94300 Kota \\ Samarahan, Sarawak, Malaysia; ${ }^{2}$ Faculty of Resource Science and Technology, Universiti Malaysia \\ Sarawak, 94300 Kota Samarahan, Sarawak, Malaysia \\ *Corresponding authors: anitaanakmuli@gmail.com \\ Received: 21 March $2019 \quad$ Accepted: 16 May $2019 \quad$ Published: 30 June 2019
}

\begin{abstract}
Studies on Baleh River with respect to aquatic fauna currently remains limited. Hence, this paper presents the species richness and composition of macroinvertebrates 14 tributaries of Upper Baleh River in Kapit Division, Sarawak. A total of 1,154 individuals from 10 orders, 43 families and 66 genera of macroinvertebrates were collected. The highest number of macroinvertebrate was taken from Naah River (201 individuals) and the least from Ukit River (15 individuals). The order Ephemeroptera was the most abundant, with $45 \%$ of the total individuals caught, followed by Trichoptera (23\%), Hemiptera (10\%), and Coleoptera (9\%). Three biological indices were used to measure the diversity of macroinvertebrate of which the values of the indices were low: Shannon diversity index (1.54-2.54), Shannon evenness index (0.33-0.89) and Margalef richness index (1.674.90). The composition of functional feeding groups varies between first and fourth order streams, which is possibly an indication of ecological effects of siltation due to logging activities in the area.
\end{abstract}

Keywords: diversity, macroinvertebrate, Upper Baleh River

Copyright : This is an open access article distributed under the terms of the CC-BY-NC-SA(Creative Commons Attribution-NonCommercial-ShareAlike 4.0 International License) which permits unrestricted use, distribution, and reproduction in any medium, for non-commercial purposes, provided the original work of the author(s) is properly cited.

\section{INTRODUCTION}

Macroinvertebrates are invertebrates characterised as being over 500 micron, and commonly inhabit sediments of freshwater ecosystem for the entire or part of their respective life cycle (Rosenberg \& Resh, 1993). They include crustaceans, molluscs, annelids and aquatic insects. Macroinvertebrates constitute a majority of river biota and occupy a variety of microhabitats, such as rocks, logs, sediments, debris and aquatic plants (Aweng et al., 2012). They perform important ecological functions, including material decomposition, nutrient cycling and the regulation of food webs through their role as consumers at intermediate trophic level (Wallace \& Webster, 1996; Covich et al., 1999). Most macroinvertebrates have long life spans and low mobility, in order to avoid disturbance and water pollution. Consequently, macroinvertebrates serve as good bioindicators of river health, by which, their presence or abundance may indicate the changes of aquatic environment. In river biomonitoring, the macroinvertebrates are grouped into functional feeding groups based on the ways of the fauna utilise and process their foods (Merrit et al., 2008). This approach had been widely used in biomonitoring of tropical river systems including Malaysia (Al-Shami et al., 2013; Che Salmah et al., 2013).

Rajang River is the longest river basin in Malaysia, with the total combined length of 565 $\mathrm{km}$, and encompasses approximately $51,000 \mathrm{~km}^{2}$ of catchment. One of the major tributaries of Rajang is Baleh River, originates from the Nieuwenhuis range in the Kalimantan-Sarawak border in the east. Baleh River plays important roles in the hydrological and biological functions in upper region of Rajang. The river is also important to the local communities living along the river for water transportation, and sources of water and food. The main threats to river systems in Asia are commonly from habitat degradation and pollution as resulting from logging, plantation, hydroelectric dam and heavy 
industrials (Dudgeon et al., 2006). The upper reaches of Baleh River had been subjected to selective logging and subsistence farming, but impacts of the activities on the river system and its faunas are not known. This study aims to document the macroinvertebrate faunas from tributaries of upper Baleh River of which this information might serve as useful baseline information for the river basin management.

\section{MATERIALS \& METHODS}

\section{Study Sites}

The present study was conducted at 14 selected streams that feed the upper reaches of Baleh River (Figure 1). The forest type of the Upper Baleh catchment is predominantly lowland mixed dipterocarp forest that had been logged about 30 years ago. Physical characteristics of each stream were assessed following modified protocols of Barbour et al. (1999) and Waterwatch Cantebury Kaitiaki Wai (2012). The assessment indicated that five streams (i.e., Senentang Kiri River, Irak River, Tor River, Ukit River \& Kian River) have poor habitat quality, where the habitats are significantly altered by logging activity. Eight streams (i.e., Penganen River, Jambu River, Puun River, Sekerangan River, Sebatu River, Senentang Kanan River, Entakun River \& Singut River) have fair habitat quality and stable environment for aquatic life.Naah River showed good habitat condition, with relatively less disturbance from logging activity. The streams are classified between first and fourth orders, following the method of Horton-Strahler (Horton, 1945; Strahler, 1957). In general, the canopy cover of first and second order streams is shaded, whereas the higher order streams had partially open canopy cover. The bottom substrates of most streams comprise sand, gravels, pebbles, cobbles, boulders and bedrock. At the downstream, characterised by relatively slower water flow, the bottom substrates are mainly sand and mud. Water of the streams in day time are fairly cool (range: $24.2^{\circ} \mathrm{C}$ $25.4^{\circ} \mathrm{C}$ ), alkaline (range: $\mathrm{pH} 7.2-7.9$ ) and contain high of dissolved oxygen (range: $7.9-8.2 \mathrm{mg} / \mathrm{L}$ ). The water was clear during dry days, and turned muddy after rain (range: 5.1-1183.1 NTU). The water conductivity ranged from 0.036 to $0.052 \mathrm{mS} / \mathrm{cm}$. The average width of the 14 streams ranged from 2.6 to $15.3 \mathrm{~m}$.

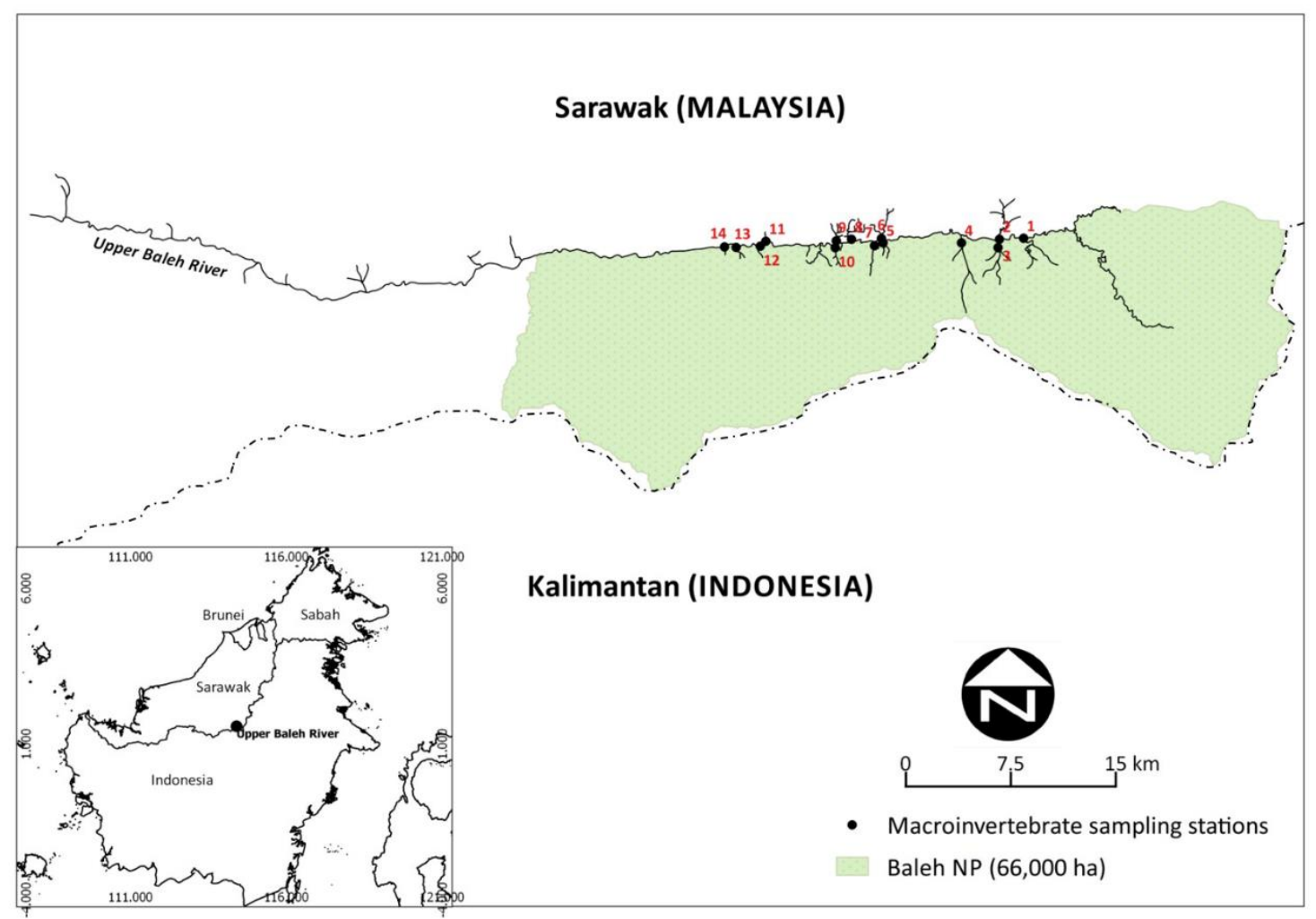

Figure 1. Map of 14 study sites in Upper Baleh River. Stream code: 1 - Entakun River, 2 - Singut River, 3 - Puun River, 4 Jambu River, 5 - Senentang Kiri River, 6- Naah River, 7 - Penganen River, 8 - Senentang Kanan River, 9 - Sebatu River, 10 - Irak River, 11 - Sekerangan River, 12 - Tor River, 13 - Kian River, 14 - Ukit River. 


\section{Macroinvertebrate Sampling and Identification}

Macroinvertebrate sampling was conducted between April 2015 and November 2016. The faunas were collected by using a kick-net (frame size $=39 \times 32$ $\mathrm{cm}$; mesh size $=400$ micron) from dominant microhabitats, such as rocks, sand and from leaf packs. The net was placed facing upstream, while the area in front of the net was agitated for about two minutes. Larger substrate, such as cobbles, boulders and pebbles were washed inside the net. Leaves, small logs and debris collected in the net were washed thoroughly and removed. The sample was transferred into a white tray for initial sorting. After sorting, the sample was put into plastic bags containing 95\% ethyl ethanol. At the base camp, the macroinvertebrates were sorted with forceps and stored in small vials of $80 \%$ ethyl ethanol. Each vial was labelled with date of sampling, location and brief description of habitat types. In the laboratory, macroinvertebrates were sorted on a petri dish and identified under a stereomicroscope to the lowest possible taxonomic level using taxonomic keys (such as those of Cheng et al., 2001; Orr, 2003; Yule \& Yong, 2004). Due to the availability of limited taxonomic keys for Malaysian taxa, the identification of macroinvertebrates to higher taxonomic level was not possible. Most of specimens were identified up to generic levels. The functional feeding groups (FFG) are classified following the morphological and behavioural adaptations of macroinvertebrate fauna in acquiring food (Cummins, 1973; Cummins \& Klug, 1979; Merritt et al., 2008). Functional feeding groups of macroinvertebrates were determined at family level following the classification of Merritt and Cummins (1996).

The diversity of macroinvertebrate in each stream was measured using Shannon diversity index $\left(H^{\prime}\right)$, Shannon evenness index and Margalef richness index from the PAST programme version 2.0 (Hammer et al., 2001). Rarefaction curve technique in EstimateS was used to estimate species richness of macroinvertebrate in each stream. This technique involves constructing a smooth species accumulation curve by randomly sampling the data, and comparing species richness across all sites at the point on the curve corresponding to the number of individuals.

\section{RESULTS AND DISCUSSION}

A total of 1,154 individuals of macroinvertebrates from 10 orders, 43 families and 66 genera were collected from Upper Baleh
River (Table 1). The highest number of individuals of macroinvertebrates were collected from Naah River (201 individuals), whereas the lowest was recorded from Ukit River (15 individuals). Aquatic insects comprise 43 families, and made up $97 \%$ of the total individuals of macroinvertebrates were caught. Ephemeroptera was the most diverse with eight families. Crustacean contains three families, whereas one family represented annelid (Oligochaeta) and snail (Gastropoda). Within the aquatic insects, orders Ephemeroptera, Trichoptera and Hemiptera were relatively high abundant with $45 \%, 23 \%$ and $10 \%$ of the total individuals caught, respectively (Figure 2). At family level of aquatic insects, the family Baetidae was the most abundant with $22 \%$ of the total individuals (Figure 2), which mainly represented from genus Platybaetis (196 individuals). Trichoptera was represented by five families, with Hydropsyche (family Hydropsychidae) was the most common genus (230 individuals).

Within the order Plecoptera, the family Perlidae has the relatively highest number of individuals compared to the Nemouridae. Perlidae, which is represented by the singleton genus, Phanoperla, was recorded from 14 streams. The aquatic bugs, Hemiptera, composed of three families, with Gerridae and Veliidae being relatively abundant than the Naucoridae. Aquatic beetles, Coleoptera, was represented by six families, but was less abundant (105 individuals). Elmidae was found in most streams, whereas Porrhorrhynchus marginatus, Elmomorphus sp. and Helocharus sp. were only sampled once. Five and six families represented the odonates (Odonata) and dipterans (Diptera), respectively. Both orders showed a low number of individual. The family Euphaeidae and Simuliidae were the most abundant within the two orders. A single family represented other macroinvertebrate groups, such as Oligochaeta (worm), Megaloptera and Lepidoptera (Insecta), each. The mollusc was few, with three species of snails (i.e., Brotia sp., Clea nigricans and Paludomus sp.) were recorded from unlogged streams, and they were absent in the main channel of logged forest streams.

Diversity indices of macroinvertebrate for Upper Baleh River are shown in Figure 3. Shannon diversity index (H') ranged from 1.29 (in Singut River) to 2.54 (in Sebatu River). The evenness and richness indices are in the range $0.33-0.89$ and $1.67-4.90$, respectively. Rarefaction curve with cut-off seven species and 15 individuals, indicates that the number of species to be 
Table 1. List of macroinvertebrate families collected from 14 tributaries of Upper Baleh River. Codes denote the functional feeding groups (FFGs): $\mathrm{SH}=$ =shredders, $\mathrm{SC}=$ =scrapers, $\mathrm{GC}=$ gathering-collectors, $\mathrm{FC}=$ filtering-collectors, $\mathrm{PD}=$ predators. Stream code: 1 -Entakun River, 2 - Singut River, 3 - Puun River, 4 - Jambu River, 5 - Senentang Kiri River, 6 - Naah River, 7 Penganen River, 8 - Senentang Kanan River, 9 - Sebatu River, 10 - Irak River, 11 - Sekerangan River, 12 - Tor River, 13 Kian River, 14 - Ukit River.

\begin{tabular}{|c|c|c|c|c|c|c|c|c|c|c|c|c|c|c|c|}
\hline \multirow{2}{*}{ Taxa } & \multirow{2}{*}{ FFG } & \multicolumn{14}{|c|}{ Study sites } \\
\hline & & 1 & 2 & 3 & 4 & 5 & 6 & 7 & 8 & 9 & 10 & 11 & 12 & 13 & 14 \\
\hline \multicolumn{16}{|l|}{ OLIGOCHAETA } \\
\hline Unidentified & $\mathrm{SC}$ & 0 & 0 & 1 & 2 & 0 & 0 & 0 & 0 & 0 & 1 & 0 & 0 & 0 & 0 \\
\hline \multicolumn{16}{|l|}{ NEOGASTROPODA } \\
\hline Buccinidae & SH & 0 & 0 & 0 & 0 & 0 & 0 & 0 & 0 & 10 & 0 & 0 & 0 & 0 & 0 \\
\hline \multicolumn{16}{|l|}{ BRACHYURA } \\
\hline Potamidae & $\mathrm{SH}$ & 0 & 0 & 0 & 0 & 0 & 0 & 1 & 0 & 0 & 0 & 2 & 1 & 0 & 0 \\
\hline \multicolumn{16}{|l|}{ DECAPODA } \\
\hline Palaemonidae & $\mathrm{SH}$ & 0 & 0 & 0 & 0 & 0 & 0 & 0 & 0 & 1 & 0 & 0 & 10 & 0 & 0 \\
\hline \multicolumn{16}{|l|}{ EPHEMEROPTERA } \\
\hline Baetidae & GC & 31 & 76 & 10 & 3 & 3 & 59 & 5 & 14 & 0 & 3 & 6 & 2 & 39 & 6 \\
\hline Caenidae & GC & 0 & 4 & 5 & 0 & 0 & 1 & 1 & 0 & 0 & 0 & 3 & 0 & 0 & 3 \\
\hline Ephemerellidae & $\mathrm{GC}$ & 5 & 0 & 4 & 0 & 0 & 49 & 1 & 3 & 1 & 5 & 0 & 0 & 1 & 0 \\
\hline Heptageniidae & $\mathrm{SC}$ & 11 & 4 & 5 & 2 & 0 & 15 & 0 & 62 & 11 & 2 & 11 & 2 & 4 & 0 \\
\hline Isonychidae & GC & 0 & 0 & 1 & 0 & 0 & 0 & 0 & 0 & 0 & 0 & 0 & 0 & 4 & 0 \\
\hline Leptophlebiidae & GC & 0 & 0 & 3 & 0 & 0 & 4 & 0 & 0 & 0 & 3 & 1 & 0 & 16 & 0 \\
\hline Neoephemeridae & $\mathrm{GC}$ & 0 & 0 & 0 & 0 & 5 & 0 & 1 & 0 & 0 & 0 & 0 & 0 & 0 & 0 \\
\hline Potamanthidae & $\mathrm{GC}$ & 0 & 0 & 0 & 0 & 0 & 0 & 0 & 0 & 0 & 0 & 2 & 1 & 2 & 0 \\
\hline \multicolumn{16}{|l|}{ ODONATA } \\
\hline Calopterygidae & PD & 0 & 0 & 1 & 0 & 0 & 0 & 0 & 0 & 0 & 0 & 0 & 0 & 0 & 0 \\
\hline Corduliidae & $\mathrm{PD}$ & 0 & 0 & 1 & 0 & 0 & 0 & 0 & 0 & 0 & 0 & 0 & 0 & 0 & 0 \\
\hline Euphaeidae & PD & 0 & 0 & 0 & 0 & 0 & 1 & 0 & 0 & 2 & 0 & 2 & 0 & 0 & 0 \\
\hline Gomphidae & PD & 0 & 0 & 0 & 1 & 0 & 0 & 0 & 0 & 0 & 0 & 0 & 0 & 0 & 0 \\
\hline Platystictidae & PD & 0 & 0 & 0 & 0 & 0 & 0 & 0 & 0 & 1 & 0 & 0 & 0 & 0 & 0 \\
\hline \multicolumn{16}{|l|}{ PLECOPTERA } \\
\hline Neumoridae & PD & 0 & 0 & 5 & 0 & 0 & 0 & 1 & 0 & 2 & 0 & 0 & 0 & 0 & 0 \\
\hline Perlidae & PD & 10 & 1 & 12 & 4 & 4 & 6 & 3 & 3 & 4 & 17 & 3 & 7 & 5 & 0 \\
\hline \multicolumn{16}{|l|}{ HEMIPTERA } \\
\hline Corixidae & $\mathrm{PD}$ & 6 & 0 & 0 & 0 & 0 & 0 & 0 & 0 & 0 & 0 & 0 & 0 & 0 & 0 \\
\hline Gerridae & $\mathrm{PD}$ & 0 & 7 & 0 & 21 & 0 & 4 & 1 & 3 & 5 & 0 & 5 & 1 & 0 & 0 \\
\hline Naucoridae & $\mathrm{PD}$ & 0 & 0 & 1 & 2 & 0 & 1 & 0 & 3 & 0 & 0 & 0 & 0 & 0 & 0 \\
\hline Vellidae & $\mathrm{PD}$ & 0 & 1 & 0 & 1 & 0 & 5 & 20 & 9 & 7 & 0 & 8 & 0 & 0 & 0 \\
\hline \multicolumn{16}{|l|}{ LEPIDOPTERA } \\
\hline Acentropinae & $\mathrm{SC}$ & 0 & 0 & 0 & 0 & 0 & 0 & 0 & 0 & 0 & 0 & 0 & 0 & 0 & 1 \\
\hline MEGALOPTERA & & & & & & & & & & & & & & & \\
\hline Corydalidae & $\mathrm{PD}$ & 2 & 0 & 0 & 1 & 2 & 2 & 0 & 0 & 1 & 6 & 0 & 0 & 3 & 0 \\
\hline TRICHOPTERA & & & & & & & & & & & & & & & \\
\hline Hydropsychidae & $\mathrm{FC}$ & 14 & 4 & 35 & 4 & 18 & 41 & 6 & 44 & 21 & 17 & 13 & 13 & 21 & 3 \\
\hline Philopotamidae & $\mathrm{FC}$ & 0 & 0 & 0 & 0 & 0 & 2 & 0 & 0 & 0 & 0 & 0 & 0 & 0 & 0 \\
\hline Rhyacophilidae & $\mathrm{FC}$ & 0 & 0 & 0 & 0 & 0 & 4 & 0 & 0 & 0 & 0 & 0 & 0 & 0 & 0 \\
\hline Psychomyiidae & $\mathrm{FC}$ & 0 & 0 & 0 & 0 & 0 & 0 & 0 & 0 & 2 & 0 & 0 & 0 & 0 & 0 \\
\hline Stenopsychidae & $\mathrm{FC}$ & 0 & 0 & 0 & 0 & 0 & 0 & 1 & 0 & 0 & 0 & 0 & 0 & 0 & 0 \\
\hline COLEOPTERA & & & & & & & & & & & & & & & \\
\hline Dryopidae & $\mathrm{PD}$ & 1 & 0 & 0 & 0 & 0 & 0 & 0 & 0 & 0 & 0 & 0 & 0 & 0 & 0 \\
\hline Elmidae & $\mathrm{SC}$ & 1 & 47 & 9 & 14 & 3 & 1 & 1 & 2 & 3 & 8 & 0 & 0 & 1 & 0 \\
\hline Gyrinidae & $\mathrm{PD}$ & 0 & 0 & 0 & 1 & 0 & 0 & 0 & 0 & 0 & 0 & 0 & 0 & 0 & 0 \\
\hline Hydrophilidae & $\mathrm{PD}$ & 1 & 0 & 0 & 0 & 0 & 0 & 0 & 0 & 0 & 0 & 0 & 0 & 0 & 0 \\
\hline Hydroscaphidae & PD & 0 & 0 & 0 & 0 & 0 & 0 & 0 & 5 & 2 & 0 & 0 & 0 & 0 & 0 \\
\hline Psephenidae & $\mathrm{SC}$ & 0 & 0 & 0 & 0 & 0 & 5 & 0 & 0 & 0 & 0 & 0 & 0 & 0 & 0 \\
\hline DIPTERA & & & & & & & & & & & & & & & \\
\hline Anthericidae & PD & 0 & 0 & 0 & 0 & 1 & 0 & 0 & 0 & 0 & 0 & 0 & 1 & 0 & 0 \\
\hline Blephariceridae & $\mathrm{PD}$ & 2 & 0 & 0 & 0 & 0 & 0 & 0 & 0 & 0 & 0 & 0 & 0 & 0 & 0 \\
\hline Chaoboridae & PD & 1 & 0 & 0 & 0 & 0 & 0 & 0 & 0 & 0 & 0 & 0 & 0 & 0 & 0 \\
\hline Chironomidae & PD & 0 & 0 & 0 & 0 & 0 & 1 & 0 & 0 & 0 & 0 & 0 & 0 & 0 & 0 \\
\hline Simullidae & $\mathrm{PD}$ & 0 & 0 & 4 & 0 & 0 & 0 & 0 & 0 & 0 & 0 & 1 & 0 & 3 & 1 \\
\hline Tipulidae & $\mathrm{PD}$ & 0 & 0 & 0 & 0 & 0 & 0 & 0 & 0 & 0 & 1 & 0 & 0 & 0 & 1 \\
\hline Total individuals & & 85 & 144 & 97 & 56 & 36 & 201 & 42 & 148 & 73 & 63 & 57 & 38 & 99 & 15 \\
\hline
\end{tabular}




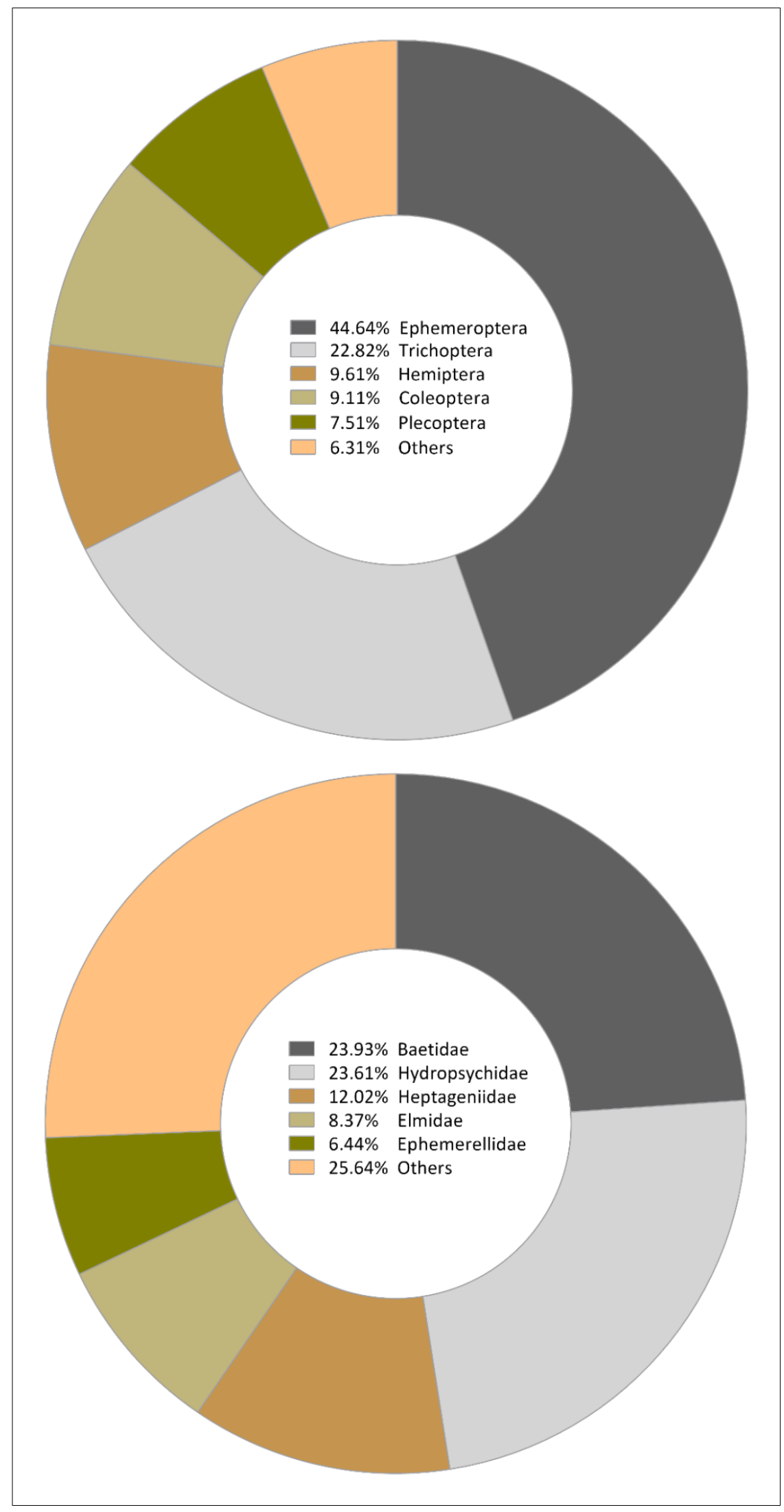

Figure 2. Composition of macroinvertebrate by orders (top) and families (bottom) in upper Baleh River 
encountered is ascending (Figure 4). The highest number of species estimated for Senentang Kanan River is 23 species, with a total of 201 individuals. The rarefaction curve estimated the number of species from Senentang Kiri River and Ukit River as low as seven species.

The Insecta dominated the macroinvertebrate fauna of Upper Baleh River. This is a typical phenomenon for many tropical Asian streams (Dudgeon, 1999). A study at the main channel of
Rajang River and the downstream tributaries had documented three bivalves, 22 species of snails, 16 polychaetes, 10 oligochaetes, 51 taxa of nymphs and larvae of aquatic insects, six crustaceans, and one species each of nematode, branchiopod and echinoderm (Shabdin, 2010). In other Malaysian freshwater habitats, Azrina et al. (2006) also documented that aquatic insects are the most diverse in Langat River, Selangor. The river system is dominated by Ephemeroptera and chironomid dipterans, whereas other orders are in small quantities. In the present study,

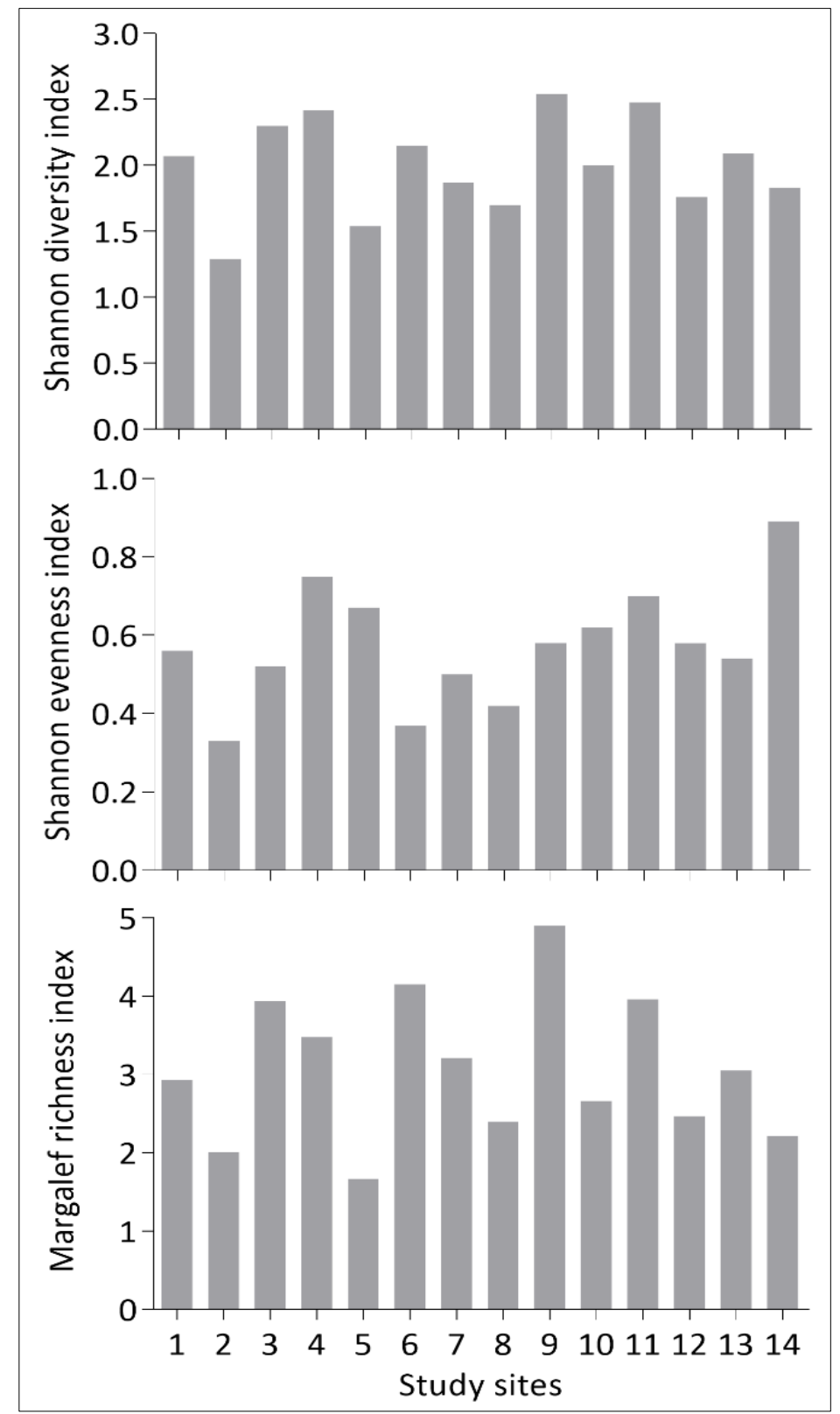

Figure 3. Three diversity indices measured for 14 tributaries of Upper Baleh River. Stream code: 1 - Entakun River, 2 - Singut River, 3 - Puun River, 4 - Jambu River, 5 - Senentang Kiri River, 6 - Naah River, 7 - Penganen River, 8 - Senentang Kanan River, 9 - Sebatu River, 10 - Irak River, 11 - Sekerangan River, 12 - Tor River, 13 - Kian River, 14 - Ukit River. 


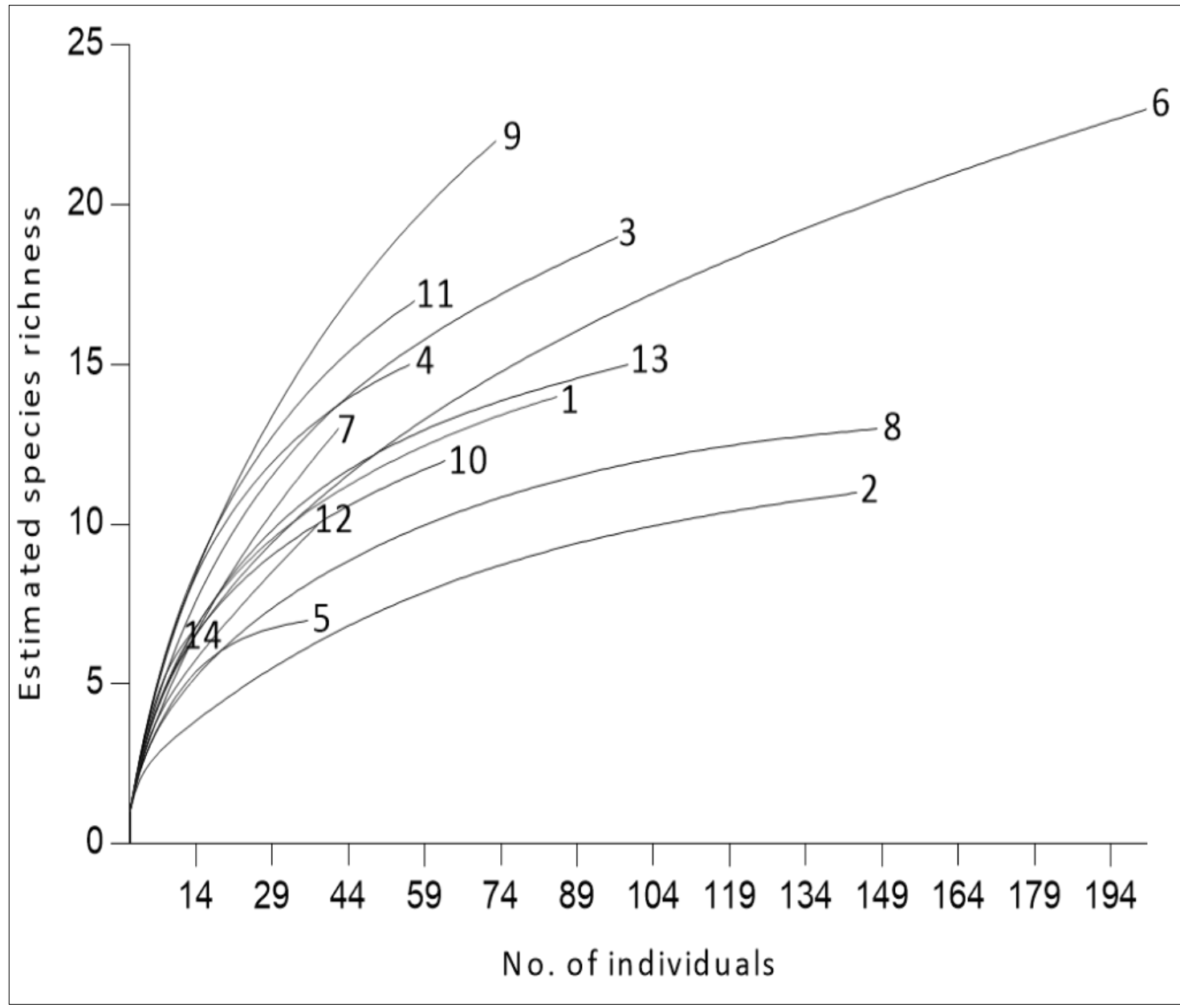

Figure 4. Rarefaction curve shows the estimated species richness of macroinvertebrates for 14 tributaries of Upper Baleh River. Stream code: 1 -Entakun River, 2 - Singut River, 3 - Puun River, 4 - Jambu River, 5 - Senentang Kiri River, 6 - Naah River, 7 - Penganen River, 8 - Senentang Kanan River, 9 - Sebatu River, 10 - Irak River, 11 - Sekerangan River, 12 - Tor River, 13 - Kian River, 14 - Ukit River.

fewer representatives were from the Annelida, Crustacea and Mollusca. Snails only recorded from unlogged forest streams. Ephemeroptera was the most abundant insect order at the Upper Baleh River. The larvae of Ephemeroptera are known to live longer in aquatic environment, and prefer fastflowing streams (Daly et al., 1998). Members of the order Ephemeroptera were abundant in Naah River possibly due to the stream being relatively less disturbed compared to other tributaries. Family Baetidae and Heptageniidae were commonly found at fast and moderate flowing water, and live on rock surfaces. The genus Hydropsyche (Hydropsychidae) was abundant, which may indicate that this filteringcollector has successfully adapted to disturbance by logging activity. Filtering-collectors commonly inhabit fast flowing water that allows them efficiently obtain organic matters (Buss et al., 2002). The
Hydropsyche sp. inhabits surface of large and stable substrates (i.e., bedrock, boulders and cobbles) and constructed "tent-like" nets to capture food particles brought about by water current (Voshell \& Reese, 2002).

The composition of functional feeding groups in the first order streams differed from fourth order streams, with the dominant group was gathering-collectors (Figure 5). The composition of predators was highest in first order stream (32.9\%), and followed by filteringcollectors $(31.5 \%)$. In the second order stream, the filtering-collectors were dominant (31.9\%), whereas less representative from the shredders $(5.2 \%)$. The filtering-collectors composed mainly of the Order Trichoptera. The compositions of gathering-collectors in the third and fourth order streams were $36.3 \%$ and $51.2 \%$, respectively. 


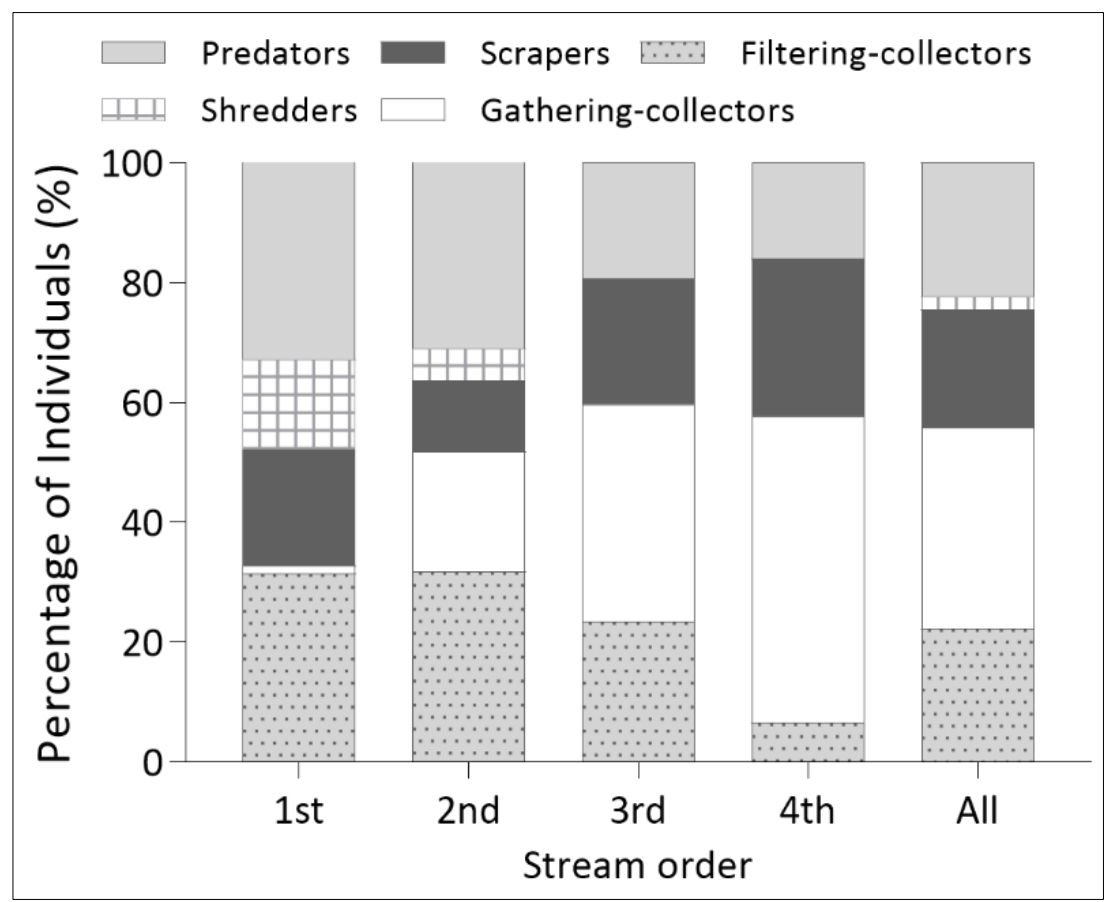

Figure 5. Composition of functional feeding groups by stream orders in upper Baleh River

The Ephemeroptera mainly represents gatheringcollectors. Shredders were less represented from all stream orders. Predators were found dominant in the first order stream, where many macroinvertebrate orders categorised into this functional feeding group, such as the Odonata, Plecoptera, Megaloptera, and Hemiptera. In this study, the shredders composed of few families of crustaceans and gastropods, indicating a heavy disturbance of the stream habitats. Shredders are known to inhibit low water temperature. Che Salmah et al. (2014) showed that the abundance and diversity of shredders reduced significantly with high water temperature. The study showed open canopy due to deforestation or naturally open riparian had resulted higher water temperature compared to shaded forest stream. The scrapers were mainly members of the families Heptageniidae and Elmidae. They are attached to rocks, and graze the surface of the rocks. The composition of functional feeding group found vary across the stream order might be due to different degree of habitat degradation along the stream.

Habitat degradation from anthropogenic activities such as logging along the stream lead affects the food availability. Wallace and Webster (1996) stated that macroinvertebrates known as intermediate trophic level consumers both bottoms-up and top-down forces in the stream ecosystem. Shredders play a vital role in forest streams through their feeding mechanisms by converting coarse particulate organic matters into fine particulate organic matters that subsequently utilize by other stream organisms (Graça, 2001). Our study showed that shredders were scarce as compared to other river systems in Malaysia (see Yule et al., 2009; Che Salmah et al., 2014). In comparison to the two studies, the tributaries in Upper Baleh had been degraded by logging that significantly reduced the amount of coarse particulate organic matters, the main food source for the shredder community. Less food available occurred at homogenous stream habitat because of logging activity. According to Iwata $e t$ al. (2003), the abundance of benthic fauna is increased with the streams with well-developed riparian forest had coarser substrates, less eroded banks, and smaller areas of depositional habitat and cover.

Brooks et al. (2005) stated that hydraulic condition created by a combination of velocity, depth and substrate roughness have a significant effect on the spatial distribution of macroinvertebrates, including aquatic insects within riffle habitats. Differences in physical and biological characteristics, such as food availability, macrohabitat richness and water condition among others, are factors that alter diversity of macroinvertebrates in the river system. Diversity of macroinvertebrate has also been associated with habitat homogeneity. The sediment type is an important determinant of macroinvertebrate composition. 
Sand has the tendency to shift and move however, burrowing species, such as worms and micro-snails and crustaceans, prefer the habitat (Uttah et al., 2013). Based on this study, it is suggested that species richness and assemblage of macroinvertebrates in Upper Baleh River is associated with the existing disturbances because of logging activities.

\section{CONCLUSION}

Aquatic insects dominate the species richness and abundance of macroinvertebrates in Upper Baleh River, whereas representatives of crustaceans, molluscs and annelids are relatively lesser. The variation of assemblages and functional feeding groups may be indicative of the impacts of logging activity on the river system and the faunas.

\section{ACKNOWLEDGEMENTS}

The authors thank Sarawak Energy Berhad, Sarawak Forest Department, the Institute of Biodiversity and Environmental Conservation, Universiti Malaysia Sarawak, WTK Timber Company, the staff of Elite Honour Camp, and the Kenyah community in Long Singut.

\section{REFERENCES}

Al-Shami, S.A., Heino, J., Che Salmah, M.R., Abu Hassan, A., Suhaila, A.H. \& Madziatul, R.M. (2013). Drivers of beta diversity of macroinvertebrate communities in tropical forest streams. Freshwater Biology, 58(6): 1126-1137.

Aweng, E.R., Suhaimi, O. \& Nur Izzati, S. (2012). Benthic macroinvertebrate community structure and distribution in Sungai Pichong, Gunung Chamah, Kelantan, Malaysia. American International Journal of Contemporary Research, 2(1): 163-167.

Azrina, M.Z., Yap, C.K., Ismail, A.R. Ismail, A., \& Tan, S.G. (2006). Anthropogenic impacts on the distribution and biodiversity of benthic macroinvertebrates and water quality of the Langat River, Peninsular Malaysia. Ecotoxicology and Environmental Safety, 64: 337-347.

Barbour, M.T., Gerristen, J., Synder, B.D. \& Stribling, J.B. (1999). Rapid Bio-assessment Protocols for use in Stream and Wadeable Rivers: Periphyton, Benthic Macroinvertebrates and Fish. Second Edition. EPA 841-D-97-002. Washington, D.C.: Environmental Protection Agency: 33. Environment, 40(1): 69-89.
Brooks, A.J., Haeusler, T., Reinfelds, I. \& Williams, S. (2005). Hydraulic microhabitats and the distribution of macroinvertebrate assemblages in riffles. Freshwater Biology, 50: 331-344.

Buss, D.F., Baptista, D.R., Silveira, M.P., Nessimian, J.L. \& Dorville, L.F.M. (2002). Influence of water chemistry and environmental degradation on macroinvertebrate assemblages $\mathrm{n}$ a river basin in South-East Brazil. Hydrobiologia, 481: 125-136.

Cheng, L., Yang, C.M. \& Anderson, N.M. (2001). Guide to the aquatic Heteroptera of Singapore and Peninsular Malaysia. The Raffles Bulletin of Zoology, 49(1): 129-148.

Che Salmah, M.R., Al-Sahmi, S.A., Madzaitul, R.M. \& Abu Hassan, A. (2013). Local effects of forest fragmentation on diversity of aquatic insect in tropical forest streams: implications for biological conservation. Aquatic Ecology, 47: 75-85.

Che Salmah, M.R., Al-Sahmi, S.A., Madzaitul, R.M., Abu Hassan, A. \& Nurul Huda, A. (2014). Distribution of detritivores in tropical forest streams of Peninsular Malaysia: role of temperature, canopy cover and altitude variability. International Journal of Biometeorology, 58: 679690.

Covich, A.P., Palmer, M.A. \& Crowl, T.A. (1999). The role of benthic invertebrate species in freshwater ecosystems: zoobenthic species influence energy flows and nutrient cycling. American Institute of Biological Science, 49(2): 119-127.

Cummins, K.W. \& Klug, M.J. (1979). Feeding ecology of stream invertebrates. Annual Review of Ecology and Systematics, 10: 147-172.

Cummins, K.W. (1973). Trophic relations of aquatic insects. Annual Review of Entomology, 18: 183206.

Davis, S., Golladay, S.W., Vellidis, G. \& Pringle, C.M. (2003). Macroinvertebrate biomonitoring in intermittent coastal plain streams impacted by animal agriculture. Journal of Environmental Quality, 32: 1036-1043.

Daly, H.V., Doyen, J.T. \& Purcell III, A.H. (1998). Introduction to Insect Biology and Diversity. New York: Oxford University Press.

Dudgeon, D. (1999). Tropical Asian Streams. Zoobenthos, ecology and conservation. China: Hong University Press.

Dudgeon, D., Arthington, A.H., Gessner, M.O., Kawabata, Z., Knowler, D.J., Le've^que, D., Naiman, R.J., Prieur-Richard, A., Soto, D., Stiassny, M.L.J. \& Sullivan, C.A. (2006). Freshwater biodiversity: importance, threats, status and conservation challenges. Biological 
Reviews of the Cambridge Philosophical Society, 81: 163-182.

Graça, M.A.S. (2001).The role of invertebrates on leaf litter decomposition in streams - a review. International Review of Hydrobiology, 86: 383393.

Hammer, Ø., Harper, D.A.T. \& Ryan, P.D. (2001). PAST: Paleontological Statistics Software Package for Education and Data Analysis. Palaeontologia Electronica, 4(1): 9.

Horton, R.E. (1945). Erosional development of streams and their drainage basins: hydropgysical approach to quantitative morphology. Geological Society of America Bulletin, 56: 275370 .

Iwata, T., Nakano, S. \& Inoue, M. (2003). Impacts of past riparian deforestation on stream communities in a tropical rain forest in Borneo. Ecological Applications, 13(2): 461-473.

Merritt, R.W., Cummins, K.W. \& Berg, M.B. (2008). An Introduction to the Aquatic Insects of North America, 4th Edition. Iowa, USA: Kendall/Hunt Publishing Company.

Orr, A.G. (2003). A guide to the dragonflies of Borneo, their identification and biology. Kota Kinabalu: Natural History Publications (Borneo).

Rosenberg, D.L. \& Resh, V.H. (1993). Freshwater biomonitoring and benthic macroinvertebrates. New York: Chapman and Hall. Shabdin, M.L. (2010). Macrofauna of Rajang River, Sarawak, Malaysian Borneo. Journal of Tropical Biology and Conservation, 7: 11-30.
Strahler, A.N. (1957). Quantitative analysis of watershed geomorphology. Transactions of the American Geophysical Union, 38: 913-920.

Uttah, C., Uttah, E., Ajang, R., Ukpong, G.I. \& Ogban, E. (2013). Comparative assessment of the relative abundance and diversity of near-shore and offshore communities of benthic macroinvertebrates off the Bonny Estuary, Nigeria. The Pacific Journal of Science and Technology, 14(2): 617-625.

Voshell, J.R. \& Reese, J. (2002). A guide to freshwater invertebrates of North America. Blacksburg, Virginia, USA: McDonald and Woodward Publishing Co.

Yule, C.M., Leong, M.Y., Liew, K.C., Ratnarajah, L., Schmidt, K., Wong, H.M., Pearson, R.G., and Boyero. L. (2009). Shredders in Malaysia: abundance and richness are higher in cool upland tropical streams. Journal of the North American Benthological Society, 28: 404-415.

Yule, C. M., and Yong, H. S. (2004). Freshwater Invertebrates of Malaysia Region. Academy Science of Malaysia, Kuala Lumpur, pp. 861.

Wallace, J.B. \& Webster, J.R. (1996). The role of macroinvertebrates in stream ecosystem function. Annual Review Entomological, 41: 115-139.

Waterwatch Cantebury Kaitiaki Wai. (2012). Waterwatch Quality Monitoring Program. Lincoln University, New Zealand. Retrieved from http://www.lincoln.ac.nz/waterwatch. 